\title{
Wzorce kulturowe, formalne instytucje a partnerstwo i dialog ${ }^{1}$
}

\section{Streszczenie}

W artykule pada wiele pytań oraz pojawiają się próby odpowiedzi w sprawie kulturowej zdolności adaptacyjnej instytucji partnerstwa i dialogu, a zwłaszcza formalnych zaleceń Unii Europejskiej. W warstwie teoretyczno-metodycznej tekstu przeważa podejście celowościowo-funkcjonalne, zorientowane na analizę instytucji formalnych w ich kulturowym otoczeniu. Wątek empiryczny stanowi problematyka partnerstwa i dialogu w europejskich funduszach strukturalnych i inwestycyjnych. Tekst jest próbą uzupełnienia dyskusji nt. kierunku i kształtu polityki publicznej o kluczowe, a spychane niekiedy na margines, wątki dotyczące praktyki. Cel, metoda i styl narracji nawiązują z jednej strony do partycypacyjnych wzorców polityki publicznej, znanych z publikacji autorów zachodnich, a z drugiej do krajowych analiz empirycznych i uogólnień teoretycznych. Wiodąca teza to prymat instytucji kulturowych nad instytucjami formalnymi i wynikająca $z$ niego potrzeba przekształcania ich wzajemnych relacji w sposób partnerski i deliberacyjny.

Słowa kluczowe: partnerstwo, dialog, współdecydowanie, instytucjonalizacja kulturowa, instytucje formalne

\section{Cultural patterns, formal institutions vs. partnership and dialogue}

\begin{abstract}
The author of the article poses a few questions and proposes some answers concerning cultural applicability of the partnership and dialogue institutions. The core of the

1 W tekście wykorzystano strukturę analizy przeprowadzoną w niepublikowanym opracowaniu przygotowanym na zlecenie Dolnośląskiej Rady Dialogu Społecznego: J. Sroka, Czy nieformalne wzorce kulturowe oraz formalne instytucje nadażaja za potrzeba partnerstwa i dialogu? Czy i ewentualnie w jaki sposób można wzmacniać potencjał strony społecznej w ramach partnerstwa $i$ dialogu w europejskich funduszach strukturalnych i inwestycyjnych?, Dolnośląska Rada Dialogu Społecznego, Wrocław 2016. Osobną część tej ekspertyzy stanowiła analiza: L. Kwieciński, Analiza praktycznych rozwiązań wzmacniania potencjału partnerów społecznych w odniesieniu do Europejskiego kodeksu postępowania w zakresie partnerstwa w ramach europejskich funduszy strukturalnych i inwestycyjnych, Wrocław 2016.
\end{abstract}


mentioned problem revolves around the ability of cultural adaptation of the formal EU norms. The theory and method used in the analysis is aim-functional which is oriented on the research into concrete cultural enclosing of formal institutions. The empirical thread of the argument is the Polish case of partnership and dialogue institutions in the European structural and investment funds. The text presents an attempt to supplement a discussion about the direction and shape of the public policy with significant threads which are often being pushed to the margin of analytical attention and public practice. On one hand, the goal, method and style of narration refers to the patterns of the participatory models of public policy known from the publications of Western authors. On the other, to the Polish empirical analyses and theoretical generalizations. The main thesis is simple as repercussion of day and night, but still seems not well understood: the predominance of cultural institutions over formal ones. It brings result in requirement of modifying the mutual relations towards more partnership and deliberative.

Keywords: partnership, dialogue, co-decision, cultural institutionalisation, formal institutions

Europejski, partnersko-dialogowy wzorzec rządzenia kształtował się w poszczególnych państwach od wielu lat - w większości w okresie powojennym, a w niektórych wypadkach, jak np. w Danii, sięga swoją historią 120 lat wstecz. Nie jest zarazem tajemnicą fakt, że wzorzec ten nie jest jednolity - mamy co najmniej tyle jego odmian, ile państw członkowskich UE, nie licząc regionów i mniejszych wspólnot, nie tylko terytorialnych, które nierzadko wypracowują własne jego warianty. We wszystkich tych wariantach splatają się zróżnicowane wątki korporatystyczne, pluralistyczne, sieciowe.

Łączy je uogólnione przyzwolenie na możliwie wolne, partnerskie sposoby uzgadniania grupowych interesów społecznych, deliberatywny styl podejmowania decyzji publicznych oraz wielopasmowość w rządzeniu publicznym. Na tym jednak uogólnione podobieństwa się kończą, a to $\mathrm{z}$ uwagi na zróżnicowane, kulturowo i sytuacyjnie uwarunkowane postrzeganie partnerstwa społecznego, a za nim deliberacji i wielopasmowości.

W Polsce dialogowy standard w miejscowym wariancie staramy się wdrażać od momentu, gdy zgodnie z rozporządzeniem rządu powołano „pierwszą” Trójstronną Komisję ds. Społeczno-Gospodarczych. Dalsze jej losy, a także instytucji regionalnych i funkcjonalnych (jak w wypadku funduszy europejskich) były różne. Generalnie można stwierdzić, że poczyniono postępy w rozwoju tych instytucji, choć trudno je uznawać za w pełni zadowalające. Od lat scentralizowanej trójstronności (a na poziomie województw czterostronności) towarzyszą niedomagania dialogu autonomicznego oraz lokalnych, sektorowych i sekcjonalnych partnerstw strategicznych.

Braki są znane i generalnie związane z problemami w pozyskiwaniu, kapitalizacji oraz operacjonalizacji zasobów poszczególnych stron. Dodatkowo, utrzymują 
się stare wzorce instytucjonalne sprzyjające bardziej administrowaniu strukturami organizacyjnymi i administrowaniu zasobami, zredukowanymi często do finansów publicznych, na które składają się dochody publiczne oraz środki pochodzące z budżetu UE, aniżeli zarządzaniu nimi w sposób bliższy założeniom towarzyszącym np. ustanawianiu unijnych funduszy strukturalnych i inwestycyjnych.

Celem opracowania jest wskazanie na najistotniejsze, zakorzenione głęboko bariery na drodze do lepszej realizacji zasady partnerstwa i dialogu, pojmowanej nie wyłącznie zgodnie z literą prawa, które to wdrażanie już powoduje niemało kłopotów, ale przede wszystkim zgodnie z jej instytucjonalno-kulturowym duchem. Problematyka ta została określona w części pierwszej artykułu, gdzie dokładniej przedstawiono: zagadnienie, pole poszukiwań oraz metodę analizy.

\section{Zagadnienia, pole poszukiwań, metoda analizy}

„Funkcjonalne wady oficjalnej struktury rodzą strukturę alternatywną (nieoficjalną), mającą za zadanie spełniać rzeczywiste potrzeby w sposób bardziej skuteczny”2.

Myśl wyrażona w powyższym cytacie posłuży za kanwę argumentacji w wielu fragmentach tego tekstu, który dedykuje się zagadnieniu rzeczywistych możliwości adaptacji instytucjonalno-kulturowych wzorców partnerstwa i dialogu w Polsce. Kategorie generalne - takie jak partnerstwo, dialog, deliberacja, wielopasmowość i wiele innych, bardziej szczegółowych, jak np. problem operacjonalizacji i kapitalizacji zasobów - nie będą tu definiowane nie tylko z uwagi na ograniczenia edytorskie. Głównym powodem jest ich wielowątkowe omówienie dostępne już od lat, zarówno w literaturze zagranicznej, jak i krajowej. Z tego też powodu nie będzie tu szczegółowych odniesień do historii dialogu społecznego w Polsce. Także problem partnerstwa i dialogu w europejskich funduszach strukturalnych i inwestycyjnych będzie jedynie zasygnalizowany, a nie dogłębnie analizowany - w nawiązaniu do istniejącego studium przypadku, które już przywołano w pierwszym przypisie ${ }^{3}$.

Tutaj pole poszukiwań związane jest z głównym pytaniem o to, dlaczego dialog społeczny i wiążący się z nim udział partnerów społecznych w podejmowaniu decyzji mają w Polsce niełatwą drogę rozwoju. W poszukiwaniu odpowiedzi pomocna będzie perspektywa celowościowo-funkcjonalna, zorientowana na analizę instytucji w ich kulturowym otoczeniu.

2 R.K. Merton, Teoria socjologiczna i struktura społeczna, tłum. E. Morawska, J. Wertenstein-Żuławski, Wydawnictwo Naukowe PWN, Warszawa 2002, s. 142.

3 J. Sroka, op.cit. 
Główną przyczyną powstawania i utrzymywania się praktyk wciąż nie do końca zgodnych nie tylko z europejskim wzorcem, ale i z formalnymi regulacjami krajowymi, jest kulturowe niedopasowanie oficjalnych rozwiązań formalno-instytucjonalnych. W efekcie tego dysonansu niektóre ważne dla dialogu rozwiązania, które mogłyby być sprawniej wdrażane w ramach obowiązujących przepisów, pozostają martwe. Nie wykorzystuje się ich, a niekiedy można nawet odnieść wrażenie, że poszczególne możliwości są administracyjnie lub środowiskowo, czy szerzej - społecznie izolowane.

Tworzy się w ten sposób specyficzny bufor, który spowalnia, a nawet uniemożliwia głębsze zakorzenienie się idei i praktyk dialogowych w ramach obowiązującego prawa. Ostateczne przezwyciężenie tej bariery umożliwia jedynie zmiana kulturowa, która ze swej natury nigdzie nie dokonuje się szybko. Aby jednak tę zmianę przybliżyć, uczynić bardziej realną, należy zwracać większą uwagę na wzajemne zachęty pomiędzy aktorami dialogu - wszyscy oni, również administracja, powinni mieć poczucie wymiernej korzyści z uczestniczenia i rozwijania dialogu społecznego. Nie powinno się tego mylić z korzyściami płynącymi z udziału w podziale zasobów, środków, pieniędzy. Chodzi o zyski w znaczeniu generalnym, publicznym, społecznym, długofalowym, a nie jedynie o mniej lub bardziej doraźne korzyści materialne.

Nie należy także utożsamiać wspomnianej korzyści z jednej strony jedynie z ogólnym poparciem (innymi słowy: legitymizacją) dla publicznych decyzji administracji (jako zysk administracji), z drugiej zaś z poszerzaniem puli dostępu do współdecydowania dla partnerów społecznych (jako zysk interesariuszy).

Postrzeganie korzyści z dialogu w taki niepogłębiony sposób to zdecydowanie za mało, aby za korzystną mogli uznawać sytuację dialogową wszyscy aktorzy społeczni, gospodarczy, polityczni. Zdecydowanie za mało, ponieważ pojmowane w podobny sposób korzyści z dialogu nie mają szans się spotkać. Wynikają z postaw zamkniętych, zorientowanych indywidualnie. Mówiąc w sposób przerysowany: w takiej sytuacji hipotetyczna władza domagałaby się poparcia ludu, a lud domagałby się umożliwienia lub poszerzenia udziału w decyzjach władzy. To znana, patowa sytuacja, stara jak świat.

Musi zatem pojawić się coś więcej: jakieś inne rodzaje zysków dla obu stron. Tak, aby korzyści były obustronne, ale i zazębiały się oraz były od siebie wzajemne zależne, aby jedne wynikały $\mathrm{z}$ drugich, jak w gęstej sieci wzajemnych zobowiązań, które są kulturowo oczywiste dla stron. To wszystko prawda, z tym jednak zastrzeżeniem, że takie wzajemne zazębianie się korzyści - związane z rozwojem pozytywnych sieci, redukcją oddziaływań tzw. brudnych interesów i brudnych wspólnot, pomnażaniem kapitału społecznego - jest efektem działania innego leku, samo zaś w sobie nie jest lekarstwem. Chcąc zaplanować lepszą czy nawet optymalną strukturę wymiany korzyści, pomylilibyśmy w ten sposób skutek z przyczyną. Rozwój sieci, rozwój transferu różnorodnych zasobów jest efektem zmian w myśleniu. W postulowanej skali nie 
mogą one przebiegać inaczej, jak tylko poprzez zmianę przeważających dotychczas w kulturze matryc postrzegania, rozumowania i działania.

Chodzi o schematy myślenia, które tworzą większe byty społeczne nazywane instytucjami kulturowymi. To rzecz z pozoru jasna, ale i ciągle ulotna: że nowego i lepszego krążenia korzyści płynących z rozwoju dialogu społecznego nie sposób zaplanować i wdrożyć samymi tylko przepisami prawa - w ten sposób tworzy się jedynie instytucje formalne, które, aby przełamać stare, niedialogowe wzorce, muszą mieć pełne poparcie wszystkich adresatów. Posługiwanie się groźbą sankcji i kolejne doprecyzowywanie dialogu w konstrukcjach świata przepisów prawnych na nic się zdadzą, gdy owe przepisy nie mieszczą się zarówno w wielu głowach, jak i w wielu sercach, tzn. nie są ani dobrze rozumiane, ani też specjalnie wyczekiwane. Jedyną drogą do wypatrywanych, przynajmniej przez część obywateli, lepszych czasów dla dialogu jest praktyka deliberacyjna.

Deliberacja jest i remedium na wspomniane niedopasowanie, i zarazem mechanizmem wyzwalającym rozwój partnerstwa. Chodzi tu o stałe kreowanie dobrej praktyki otwartego dialogu bliskiego, ale i pozbawionego specyficznego kartelowego nalotu, tj. dialogu zogniskowanego na sprawach publicznych, a nie na korzyściach partykularnych i grupowych. Dialogu, który skłaniałby uczestników do spoglądania na problemy społeczne z różnych perspektyw, z użyciem wielu paradygmatów, wielu punktów widzenia. Deliberacyjny dialog powinien zmierzać do wypracowywania nowych sposobów uzgadniania interesów, nowych argumentów, nowych metod pomiaru oraz stopniowego wykluczania argumentów starych, zużytych metafor, zbyt kontrowersyjnych sposobów oceny i ewaluacji.

Deliberacja ma za zadanie rozwijać świadomość, że - podobnie jak „wspólne pastwisko", znane ze słynnego teorematu podejmowanego m.in. przez G. Hardina ${ }^{4}$ i E. Ostrom ${ }^{5}$ - tak też wspólny rezerwuar publicznych środków i możliwości musi być podtrzymywany cyrkulacją i wymianą różnorodnych zasobów pomiędzy wszystkimi uczestnikami dialogu.

Dla prawdziwego rozwoju partnerstwa i dialogu potrzeba więc także, jak już wspomniano, bardziej rozwiniętego podejścia transakcyjnego, potrzeba sieciowej wymiany zasobów, której towarzyszy przejrzystość. Nie należy przy tym mylić wspomnianego tu podejścia transakcyjnego ze zwykłymi relacjami rynkowymi. Wymiana, o której tu mowa angażuje bowiem nie tylko, a nawet nie przede wszystkim, mechanizmy rynkowe, ale także układy hierarchiczne oraz sieci społeczne, gospodarcze i polityczne.

G. Hardin, The Tragedy of the Commons, "Science, New Series” 1968, Vol. 162, s. 1243-1248.

E. Ostrom, Collective Action and the Evolution of Social Norms, "Journal of Economic Perspectives" 2000, Vol. 14, s. 137-158; E. Ostrom, Beyond Markets and States: Polycentric Governance of Complex Economic Systems, "American Economic Review" 2010, Vol. 100, s. 641-672. 
Szerzej także należy w tym wypadku pojmować zasoby, wśród których będą nie tylko wymierne środki materialne i zaplecze organizacyjne, ale także bardziej ulotne możliwości, jak np. możliwości koalicyjne czy trudno mierzalny, ale niezaprzeczalnie kluczowy potencjał w postaci zaufania. Zasoby tego rodzaju najskuteczniej rozwija praktyka deliberacyjna.

Do dalszych analiz posłużą składowe przywołanej wcześniej myśli R. Mertona. Rozważane i proponowane (a nie rozstrzygane) będzie:

1) to, co w interesującym nas obszarze stanowi strukturę oficjalna,

2) jak w odniesieniu do tejże struktury rozumieć strukturę alternatywna, a także

3) czym są rzeczywiste potrzeby oraz kto, tzn. jacy interesariusze mogą czy też powinni za tymi potrzebami stać.

Zastanowimy się także nad możliwościami przełamywania starych schematów ograniczających dialog i partycypację. W toku proponowanej argumentacji uwzględnione zostanie oddziaływanie trzech głównych mechanizmów koordynujących we współczesnych społeczeństwach, tj. sieci, rynków, hierarchii. Odniesiemy je do polityki publicznej, wskazując przy okazji specyfikę tej ostatniej oraz rolę, jaką w polityce publicznej pełnią dialog, deliberacja, współdecydowanie z udziałem partnerów społecznych. Podjęta zostanie również próba oceny możliwości korygowania obowiązującego stylu decyzyjnego w polityce publicznej i będą zaproponowane kierunki działań, które mogłyby zbliżać do zmian pożądanych w świetle proponowanej w tekście interpretacji.

Wątki te przewijają się przez całą argumentację, bo i wymagają wielu odniesień, są wielowymiarowe. Dlatego nie zostały wydzielone i opatrzone osobnymi tytułami, a podział tekstu został podporządkowany zamysłowi ukazania interesujących nas problemów w kontekście nowoczesnej polityki publicznej. Za wkład empiryczny posłużą dalej przykłady zaczerpnięte $\mathrm{z}$ analizy przypadku w postaci dialogu i partnerstwa we wdrażaniu europejskich funduszy strukturalnych i inwestycyjnych. Jak już wspominano, przypadek funduszy nie będzie jednak analizowany szczegółowo, nie tylko z braku miejsca, ale przede wszystkim dlatego, że został on poddany analizie w niepublikowanym opracowaniu przygotowanym przez autora w grudniu $2016 \mathrm{r}$. na zlecenie Dolnośląskiej Rady Dialogu Społecznego ${ }^{6}$.

\footnotetext{
6 J. Sroka, op.cit.
} 


\section{Kulturowe zakorzenienie instytucji a słaba siła partnersko-dialogowych formalizmów}

Nawiązując do słów R. Mertona - strukturę oficjalną dialogu społecznego tworzą, rzecz jasna, formalne ramy dialogu społecznego. To jednak, że ramy prawne nie przesądzają o ostatecznym kształcie oraz jakości danej instytucji nie tylko w sposób intuicyjny przeczuwamy, ale i dobrze wiemy z dotychczasowych doświadczeń. Obowiązujące rozwiązania formalne stwarzają np. możliwość zarówno szerszej, jak i głębszej partycypacji interesariuszy w publicznych procesach decyzyjnych. Rzeczywiste okoliczności jednak ten udział ograniczają - dlaczego?

Dialogowe formalizmy będą skuteczniejsze tam, gdzie istnieją społeczno-kulturowe podwaliny pod ich działanie. Tam, gdzie zanim się pojawiły, kształtując zarys formalnych instytucji, wcześniej ugruntowały się prodialogowe sposoby obrazowania świata i praktykowania partnerstwa oraz dialogu - w rozmaitych oddolnych działaniach społeczności, w zróżnicowanych obszarach ich życia zbiorowego oraz różnymi metodami.

Przykładowo, jednym z europejskich partnersko-dialogowych schematów jest, wdrażany w państwach członkowskich UE, Europejski kodeks postępowania w zakresie partnerstwa w ramach europejskich funduszy strukturalnych i inwestycyjnych? ${ }^{7}$ Kodeks jest rozporządzeniem sformułowanym w formie instrukcji, która ustanawia, ale i w założeniu ma przybliżać problematykę:

1) identyfikacji partnerów,

2) zaangażowania partnerów w przygotowywanie związanych $\mathrm{z}$ funduszami umów i programów,

3) formułowania zasad i procedur dla komitetów monitorujących,

4) zaangażowania partnerów w przygotowanie naborów wniosków, sprawozdań z postępów oraz monitorowanie i ewaluację programów,

5) wzmacniania zdolności instytucjonalnych partnerów.

Zwięzłe zapisy Kodeksu są przykładem formalnej wykładni nowej, sekcjonalnej instytucji dialogowej w międzysektorowym module polityki publicznej obszaru UE. Sekcjonalnej, ponieważ partnerstwo ujmowane jest jako jeden z mechanizmów modulujących wdrażanie konkretnych programów związanych z uruchamianiem funduszy. Same zaś fundusze to zasoby, dzięki którym, w założeniu, możliwa jest

7 Zob. Rozporządzenie delegowane KE, nr 240/2014, z dnia 7 stycznia 2014 roku, w sprawie Europejskiego kodeksu postępowania w zakresie partnerstwa w ramach europejskich funduszy strukturalnych $\mathrm{i}$ inwestycyjnych. 
operacjonalizacja i kapitalizacja generalnych celów sektorowej polityki unijnej, jak np. tych, które zawiera strategia Europa $2020^{8}$, a także celów zawartych w krajowych i regionalnych planach rozwojowych.

Lakoniczne, a zarazem niekiedy daleko idące stwierdzenia i zalecenia formalne, podobne do tych z cytowanego Kodeksu, są siłą rzeczy lepiej rozpoznawane i łatwiej rozwijane tam, gdzie praktyki dialogowe mają długi rodowód, a zdolność do uzgadniania, ucierania interesów grupowych, duch dobrze rozumianego partnerstwa i deliberacji są dobrze zakorzenione i kulturowo utrwalone, czyli kulturowo zinstytucjonalizowane ${ }^{9}$. Prawdziwa adaptacja kulturowa wskazanych elementów czyni nowoczesną politykę publiczną zarówno możliwą, jak i skuteczną. Z kolei niedomagania $\mathrm{w}$ tej sferze mogą sprawić, że deliberacyjnie nastawiona polityka publiczna będzie się jawić jako bardziej enigmatyczna i niedopasowana do lokalnej rzeczywistości w porównaniu z tradycyjnym administrowaniem i towarzyszącymi mu często relacjami klientelistyczno-patronackimi.

Trzon nowoczesnej polityki publicznej stanowi tzw. wielopasmowe rządzenie czy, mówiąc inaczej, rządzenie publiczne (public governance). Tego typu aktywność koordynacyjna i interwencyjna jest procesem, co oznacza, że stanowi ciąg celowych, przyczynowo-skutkowo powiązanych sekwencji działań, działań sprzężonych ze sobą i z siebie wynikających. Trzeba zarazem mocno w tym miejscu podkreślić, że ono samo, tj. rządzenie wielopasmowe (zarządzanie publiczne), również jest uwarunkowane procesualnie. Rządzenie wielopasmowe ani nie pojawia się więc samo z siebie, ani też nie wystarczy go formalnie zaprojektować, aby rzeczywiście ziściło się ono w praktyce. Rządzenie wielopasmowe wynika z deliberacji, a dokładniej mówiąc: jest $\mathrm{w}$ istocie jedną z funkcji deliberacji.

Nieprzypadkowo mamy tu do czynienia ze swoistymi pętlami działań. Nowoczesna polityka publiczna jest samoreferencyjna, jej kolejne programy wynikają z wcześniejszych, w uchwytnym sensie same siebie określają, a to za sprawą sieciowych wzmocnień i podzielanych przez aktorów rozróżnień w postrzeganiu zjawisk i problemów. Jeśli tak nie jest, wówczas mamy do czynienia z burzącym te sekwencje nadmiernym oddziaływaniem swobodnego uznania w decyzjach publicznych, a więc ze znanym z badań nad administracją urzędniczym decydowaniem dyskrecjonalnym, charakterystycznym dla tradycyjnego, tj. biurokratycznie scentralizowanego wzorca wyłaniania rozstrzygnięć publicznych. Chodzi o to, że nie można mówić

8 Komisja Europejska: Komunikat Komisji, Europa 2020 - Strategia na rzecz inteligentnego i zrównoważonego rozwoju sprzyjającego włączeniu społecznemu, http://eur-lex.europa.eu/LexUriServ/ LexUriServ.do?uri=COM:2010:2020: FIN:PL:PDF, dostęp: 24.07.2017.

9 Szerzej zob. np.: J. Sroka, Europejskie stosunki przemysłowe w perspektywie porównawczej, Wydawnictwo Uniwersytetu Wrocławskiego, Wrocław 2000. 
o nowoczesnej polityce publicznej, o rządzeniu wielopasmowym i o deliberacji, bez prawdziwej deliberacji, prowadzonej w tych obszarach, które są dla niej wydzielane we współczesnych państwach prawdziwie otwartych na oddziaływania obywatelskie.

Jednym z takich obszarów jest, służące tu za pomocniczy przykład, partnerstwo w ramach europejskich funduszy strukturalnych i inwestycyjnych. Gdy weźmiemy pod uwagę dotychczasową argumentację, wówczas jasne stanie się dla nas zróżnicowanie tempa, w jakim różnorodne partnerstwa, w tym również te funduszowe, są budowane w obszarze UE. Prędzej i z lepszymi efektami są budowane tam, gdzie doszło do wcześniejszego upowszechnienia, internalizacji wzorców dialogowych.

Natomiast później i inaczej - np. z nalotem etatystycznym czy kartelowym - budowane są tam, gdzie do takiego zakorzenienia póki co nie doszło i w związku z tym większym zrozumieniem cieszą się bardziej autorytatywne formy decydowania znane z praktyki realizowanej wedle sformułowanego przez M. Webera tzw. racjonalnego modelu administracji publicznej, w którego cieniu rozwijają się niekiedy takie struktury alternatywne, jak: klientelizm, układy koalicyjno-patronackie, wpływy nieprawomocne czy parantelizm ${ }^{10}$.

To właśnie m.in. z tych powodów B. Guy Peters określił tradycyjny model administrowania sprawami publicznymi mianem „religii minionego czasu”. Religii, która nakazywała wiarę w decyzjonizm administracyjny, w racjonalność tradycyjnie zorganizowanego aparatu publicznego, który trafnie podejmował i skutecznie wdrażał decyzje, działając w sposób samodzielny, a zarazem w sposób nadrzędny i hierarchicznie odizolowany od obywateli. Dziś coraz częściej nie tylko podaje się w wątpliwość racjonalizm decyzji dyskrecjonalnych, ale i ukazuje się konkretne dowody potwierdzające to przeczucie. Na dowodach tych, w ramach tzw. evidence based theory, od lat 90. XX w. buduje się uzasadnienia dla obecnie promowanego wzorca partycypacyjnego, czyli dla nowoczesnej polityki publicznej ${ }^{11}$.

Jednak dla wprowadzenia praktyk nowej polityki publicznej, dialogowo-partycypacyjnej polityki publicznej opartej na dowodach, potrzebna jest wspominana już kulturowa zmiana instytucjonalna. Bez niej reformy się „zatrą” - działa ona jak instytucjonalny smar dla nowych praktyk. Ta, jak się wydaje, dosyć jasna konstatacja nie znajduje jednak odzwierciedlenia w myśleniu i działaniu charakterystycznym dla instytucji starego typu. Większości ludzi często to nie przeszkadza, bo i nie dostrzegają problemu, którego dostrzec nie mogą, tkwiąc w okowach myślenia starego typu.

10 B.G. Peters, Administracja publiczna w systemie politycznym, tłum. K. W. Frieske, Scholar, Warszawa 1999 , s. 216-245.

11 Zob. np. G. Majone, Dowody, argumenty i perswazja w procesie politycznym, tłum. D. Sielski, Scholar, Warszawa 2004; A. Zybała, Polityki publiczne, Krajowa Szkoła Administracji Publicznej, Wyd. Kontrast, Warszawa 2012, s. 29, 206-207. 
Prawdziwa zmiana instytucjonalna wymaga wytrwałości oraz upowszechniania dobrych praktyk partnerstwa i dialogu we własnych środowiskach, we własnych zakładach i profesjach, w relacjach z podwładnymi, kontrahentami, klientami, sąsiadami, wyborcami itp., a nie jedynie lobbingu zorientowanego na poszerzanie własnego dominium związanego z interesami partykularnymi i grupowymi. Wypatrywana zmiana instytucjonalna, ugruntowująca partnerstwo i dialog w sposób kulturowy, nie nastąpi pod presją nacisku grupowego, przewagi reprezentacji czy regulacji formalnej. Pełne, prodialogowe zmiany instytucjonalne nie zachodzą w sposób mechaniczny, asymetryczny, jednostronny.

\section{Praktykowanie kooperacji i wzajemne zaufanie - fundamentalne elementy partnerstwa i dialogu}

Skuteczniej domagać się rzeczywistych zmian, rozwoju rzeczywistego partnerstwa można tylko wówczas, gdy samemu się rozwojowi partnerstwa hołduje - nie tylko jednostronnie, tzn. oczekując pogłębienia partnerskiej postawy przez administrację, ale i we własnej codzienności organizacyjnej, we własnych środowiskach społecznych - od wspólnot sąsiedzkich, przez wspólnoty profesjonalne i zawodowe, po wspólnotę parlamentarną, można by rzec. Tymczasem, jak wskazują publikowane od wielu lat analizy, takie kategorie kulturowo-normatywne, jak: dobro wspólne, praca dla innych czy zaufanie do ludzi nie są na tyle w Polsce zakorzenione, aby mogły skutecznie kompensować oddziaływanie orientacji indywidualnych - to one nadal zdecydowanie górują $\mathrm{w}$ wielu relacjach - m.in. w pracy, w biznesie i w sferze publicznej $^{12}$. Nie chodzi o to, żeby orientacje indywidualne zastąpić kolektywnymi, to niemożliwe, ale możliwe jest uzupełnienie ich o komponent, którego w rodzimej kulturze wciąż brak. Komponent związany ze zwyczajami wzajemnego uszanowania interesów (nie tylko biznesowych!) oraz ich uzgadniania. Brak tego właśnie komponentu w społecznym krwiobiegu kulturowym nie tylko utrudnia, spowalnia, a czasem wręcz uniemożliwia rozwój dobrze zakorzenionego partnerstwa i dialogu, ale i przyczynia się do rozwoju konkurencyjnych struktur nieformalnych, o których mówi motto przyjęte w niniejszym opracowaniu.

Struktury nieformalne oparte są na starszych wzorcach kulturowych. Są one dla wielu wygodniejsze, już choćby z tego powodu, że są znane, swojskie i ich stosowanie nie wymaga wysiłku, również emocjonalnego i intelektualnego, czego nie można

12 Zob.: J. Czapiński, Stan społeczeństwa obywatelskiego, w: Diagnoza społeczna 2015. Warunki i jakość życia Polaków, red. J. Czapiński, T. Panek, Rada Monitoringu Społecznego, Warszawa 2015. 
powiedzieć o nowych wzorcach, które próbuje się formalnie wprowadzać. Poza tym, na co zwracali uwagę dwaj autorzy: M. Crozier i E. Friedberg, „każda zmiana jest niebezpieczna, ponieważ w sposób nieunikniony narusza warunki (...) gry i grozi człowiekowi utratą swobody działania oraz panowania nad określonymi źródłami władzy, modyfikując bądź eliminując sfery niepewności, które mógł on kontrolować"13. Tę myśl można i warto rozpatrywać w różnych kontekstach krajowych, regionalnych i lokalnych, w różnych kontekstach międzyludzkich i społecznościach, których jesteśmy członkami.

Trudno dyskutować z tym, że rozwojowi kultury propartycypacyjnej służy wyższy poziom zaufania oraz kapitału społecznego. Wzajemne zaufanie to wartość nie do podważenia, w każdych zwykłych warunkach - wyłączywszy niektóre skrajne sytuacje, w których stawką jest przetrwanie, co jest charakterystyczne dla brutalnych ataków, konfliktów zbrojnych, głodu, epidemii czy katastrof. Nawet jednak w takich sytuacjach jest miejsce dla zachowań wspólnotowych, solidarystycznych, bezinteresownych, wielkodusznych. Jest, ponieważ zawsze pozostaje nieco miejsca dla odruchów serca. Inaczej nie bylibyśmy ludźmi.

W każdej sytuacji możemy korzystać z renty, jaką daje nam wzajemne zaufanie - wiemy to z doświadczeń własnych i z wielu przykładów z otaczającego nas świata. W tym sensie wartość wzajemnego zaufania jest naoczna i nie wymaga tutaj dodatkowych uzasadnień. Podobnie jest w wypadku kapitału społecznego, który jest tym wyższy, im wyższe jest zaufanie. Towarzyszą mu tzw. więzi pomostowe, łączące ze sobą poszczególne wspólnoty, środowiska, grupy i współtworzące rozwinięte struktury sieciowe w społeczeństwie obywatelskim. Chodzi tu o sieci nieskażone zjawiskami znanymi ze wspominanych już tzw. brudnych wspólnot, których domeną są rozmaite nieczyste relacje i nie do końca czyste interesy. Warto przy tym stale pamiętać o zagrożeniu degeneracją kapitału społecznego - relacje z nim kojarzone mogą, za sprawą szemranych praktyk obsuwać się w obszar brudnych interakcji. Wypada zgodzić się zatem z opinią, że "granica między brudną wspólnotą (...) a »dobrym« kapitałem społecznym jest często - wbrew temu, co się potocznie przyjmuje - bardzo płynna"14.

Zaufanie i kapitał społeczny trzeba pielęgnować, inwestować w nie, stale odnawiać i być zarazem wyczulonym na naruszanie dobra wspólnego oraz na niebezpieczne kartele interesów. Łatwo to powiedzieć, zdecydowanie trudnej praktykować. Nie ma jednak żadnej drogi na skróty. Jest jedynie droga wstecz, ku znanym nam relacjom

13 M. Crozier, E. Friedberg, Człowiek i system. Ograniczenia działania zespołowego, tłum. K. Bolesta-Kukułka, PWE, Warszawa 1982, s. 358-359.

14 A. Kiersztyn, Granice brudnej wspólnoty, w: Idee naukowe Adama Podgóreckiego, red. J. Kwaśniewski, J. Winczorek, Prace Katedry Socjologii Norm, Dewiacji i Kontroli Społecznej IPSIR UW, tom X, PTS - IPSIR UW, Warszawa 2009, s. 180. 
przesiąkniętym podejrzliwością, izolacją poszczególnych grup społecznych, egoizmem w różnych odmianach, kartelowością, wykluczaniem, eksponowaną wyższością, a czasami niemal bezinteresowną zawiścią, złośliwością itp. Nie tworzą one warunków sprzyjających rozwojowi partnerstwa i dialogu. W opisany negatywnie sposób również można się rozwijać, tyle że wyraźnie wolniej, ponosząc wyższe koszty transakcji społecznych i rynkowych, a zarazem oddając pole w rywalizacji międzynarodowej społeczeństwom nastawionym bardziej kooperacyjnie.

Wzrost kapitału społecznego i zaufania przyczynia się do rozwoju otwartych postaw, kooperacji, wzmacnia wrażliwość na dobro publiczne, sprzyja zrzeszeniowości. Tymczasem w Polsce „skłonność do stowarzyszania się, gdy przynależność do organizacji stała się po zmianie systemu w pełni dobrowolna, gwałtownie spadła z 30,5 proc. w 1989 r. (World Value Survey) do 14,8 proc. i utrzymała się na tym poziomie do dzisiaj (w 2015 r. 13,4 proc.). Lokujemy się pod tym względem, podobnie jak pod względem zaufania, na końcu grupy krajów objętych badaniem European Social Survey w 2002 r." ${ }^{15}$.

Jak pisze J. Czapiński, „większość badaczy kapitału społecznego podkreśla jego pozytywną rolę dla rozwoju gospodarczego. Kapitał społeczny ma owocować zamożnością - czy to poszczególnych osób, czy wspólnot. W raporcie z poprzedniej edycji Diagnozy (...) omówiliśmy szczegółowo ekonomiczne znaczenie kapitału społecznego w przekroju międzynarodowym. Stwierdziliśmy tam, że sprzyja on wzrostowi gospodarczemu, mierzonemu PKB na mieszkańca, ale tylko w krajach rozwiniętych. W krajach rozwijających się decydujące znaczenie ma kapitał ludzki mierzony poziomem wykształcenia mieszkańców. Kapitał ludzki wydaje się istotnym predyktorem także w krajach rozwiniętych, ale w istocie wynika to $z$ silnego w tych krajach pozytywnego związku poziomu wykształcenia z ogólnym zaufaniem i innymi wskaźnikami kapitału społecznego. Gdy w równaniu regresji wielokrotnej uwzględnimy naraz poziom wykształcenia i zaufania, okazuje się, że w krajach rozwijających się kapitał ludzki pozostaje istotnym predyktorem $\mathrm{PKB}$, natomiast w krajach rozwiniętych jego moc wyjaśniającą konsumuje kapitał społeczny”16. „Badania międzynarodowe dowodzą, że kapitał ludzki jest ważniejszą niż kapitał społeczny przesłanką rozwoju w krajach uboższych, do których ciągle jeszcze zaliczyć można także Polskę. Po przekroczeniu jednak pewnego progu zamożności decydującego znaczenia dla dalszego rozwoju nabiera kapitał społeczny"17.

15 J. Czapiński, op.cit., s. 335.

16 Ibidem, s. 339.

17 Ibidem, s. 344. 
W polskich regionach notuje się także zróżnicowanie zaufania i kapitału społecznego. We wszystkich województwach wskazania te oscylują wokół niechlubnej, bo niskiej średniej krajowej. Niektóre obszary lokują się nawet i dużo poniżej średniej krajowej, która tak mocno odbiega od średniej europejskiej. I tak: „najniższa wrażliwość jest notowana w województwie warmińsko-mazurskim, tódzkim i wielkopolskim, a największa w podlaskim, małopolskim i dolnośląskim. Najbardziej wrażliwi są pracownicy sektora publicznego, a najmniej bezrobotni. I w tym przypadku wynika to $\mathrm{w}$ znacznej mierze $\mathrm{z}$ różnic $\mathrm{w}$ poziomie wykształcenia. $\mathrm{W}$ porównaniu z 2011 rokiem niemal we wszystkich grupach nastąpił wzrost odsetka osób wrażliwych na naruszanie dobra wspólnego; spadł tylko w woj. wielkopolskim, lubelskim i śląskim oraz w dużych miastach (200-500 tys. mieszkańców)"18.

Podsumowując, wróćmy raz jeszcze do cytatu przyjętego za motto dla tego opracowania, głoszącego - przypomnijmy, że „funkcjonalne wady oficjalnej struktury rodzą strukturę alternatywną (nieoficjalną), mającą za zadanie spełniać rzeczywiste potrzeby w sposób bardziej skuteczny”. W świetle sformułowanej argumentacji widzimy, że strukturę oficjalną stanowią instytucje formalne mające służyć partnerstwu i dialogowi. $\mathrm{Z}$ uwagi na przywoływane parametry są one jednak niezakorzenione. W ich cieniu trwają i ewoluują struktury nieformalne, które stanowią splot pozostałości dawnych, silnie hierarchicznych norm i wzorów postępowania, a także nowych form relacji, m.in. kartelowych, klientelistycznych, patronackich, ale także dialogowych, $\mathrm{z}$ tym że swoiście zredukowanych, by nie powiedzieć skarlałych, za sprawą oddziaływania środowisk, w których przychodzi im się rozwijać. Tak pokrótce działa wyczuwalna niemal na co dzień, ale zarazem często trudna do zwerbalizowania żelazna obręcz ograniczająca rozwój partnerstwa i dialogu, a także spowalniająca postęp w zakresie wzrostu zaufania i kapitału społecznego. Postęp jest tym trudniejszy, że wskazane bariery warunkują się zwrotnie. Czy istnieje zatem wyjście z tej sytuacji? Tak, wskazują na to uznane ustalenia dotyczące dobra wspólnego oraz aktywności grup interesu autorstwa M. Olsona ${ }^{19}$, które w swojej trafnej argumentacji wykorzystała i zmodyfikowała E. Ostrom ${ }^{20}$. Autorka wyszła w swoim wywodzie od zanegowania pesymistycznego, a nawet wręcz katastroficznego obrazu możliwości długoterminowego kreowania, odtwarzania i pomnażania dobra wspólnego, jaki w latach 60 . XX w. nakreślił G. Hardin ${ }^{21}$.

18 Ibidem, s. 316.

19 M. Olson, The Logic of Collective Action: Public Goods and the Theory of Groups, Harvard University Press, Cambridge 1965, 1971.

20 E. Ostrom, op.cit.

21 G. Hardin, op.cit. 
E. Ostrom podkreśla znaczenie myślenia heurystycznego w rozumowaniu jednostek ludzkich. Uwypukla efekty myślenia, do których ludzie dochodzą przy użyciu tzw. heurystyk, tzn. za pomocą prostych skojarzeń, m.in. poprzez transferowanie pojęć z jednej dziedziny życia do drugiej, poprzez odnawianie i redefiniowanie znanych dobrze pojęć w taki sposób, aby oddawały sedno nowych problemów czy komunikowanie w zespole, który np. w wyniku tzw. burzy mózgów dochodzi do nowych koncepcji i innowacyjnych rozwiązań. Takimi m.in. sposobami jednostki, jeśli tylko widzą w tym interes i czują, na czym polega działanie kolektywne, mogą dochodzić do coraz bardziej skomplikowanych rozwiązań. Uczą się dzięki przekładaniu na dany problem własnych doświadczeń, bliskich im skojarzeń. Uczą się także od siebie, mają zarazem skłonność do upodabniania swoich poglądów, jeśli tylko sobie ufają i chcą koncepcyjnie myśleć i otwarcie współpracować. A chcą tym bardziej, jeśli dzięki zaufaniu czują się w danym łańcuchu wymiany zasobów coraz bardziej swojsko, a zarazem widzą w tym łańcuchu interes własny, ale i interes wspólny, publiczny, społeczny. Zrozumienie nowego problemu, idei, sposobu działania jest więc dla nich w jakimś sensie opłacalne, jest im na rękę, redukuje dotychczasowe niewygody wzajemnych relacji. Poziom zaufania jest przy tym wprost proporcjonalny do liczby transakcji oraz poczucia satysfakcji z uczestniczenia w nich. Im wyższe zaufanie, tym niższe koszty transakcji.

\section{Reformistyczne pułapki w partnerstwie i dialogu}

W odniesieniu do dialogu i partnerstwa płynie z powyższego wniosek, że nie wystarczy wdrażać prodialogowe reformy formalne. Nie wystarczy wskazywać na fakt istnienia scentralizowanych terytorialnie lub sektorowo rad, komisji, komitetów, grup roboczych itp. Działania tych ciał należy w praktyce stale decentralizować i dekoncentrować, na co zresztą pozwalają istniejące rozwiązania formalne, trzeba z nich tylko pełniej korzystać. Dzięki rozumianej w ten sposób praktycznej decentralizacji i dekoncentracji pojawia się więcej obiegów zasobów, w których uczestniczy większa liczba aktorów, uczą się oni od siebie nowych praktyk w coraz większej skali. Dokonuje się liczniejszych transakcji, których koszty, jak wspomniano, maleją, a to $z$ kolei zwiększa prawdopodobieństwo upowszechniania się poczucia satysfakcji $\mathrm{z}$ uczestnictwa w partnerstwie i dialogu.

Wraz z satysfakcją rośnie uogólnione zaufanie horyzontalne (sieciowe: ludzi do ludzi) oraz wertykalne (hierarchiczne: ludzi do hierarchii i organizacji, a zarazem ich funkcjonariuszy do klientów). Z kolei wyższy poziom zaufania zachęca do większego 
angażowania w inicjowany w imię dobra wspólnego proces cyrkulacji zasobów, jaki powinien odbywać się w ramach interakcji partnerskich i dialogowych.

W tym sensie blokowanie czy opóźnianie rozwoju partnerstw, nie tylko w funduszach rozwojowych, ale generalnie - w kraju, jest działaniem antyrozwojowym. Jest zarazem marnotrawstwem zasobów tkwiących w społecznych i gospodarczych powiązaniach sieciowych. Stanowi też przykład niewykorzystania szans związanych z upowszechnianiem jednego z kluczowych mechanizmów współczesnej polityki publicznej - publicznego koordynowania $\mathrm{z}$ wykorzystaniem wspomnianych sieci, czyli tzw. rządzenia wielopasmowego (public governance). Jest wreszcie rezultatem typowego oddziaływania nieformalnego, generowanego w cieniu formalnych rozwiązań. Oddziaływania chroniącego dobrze znaną, bo i z dawna w Polsce istniejącą sferę niepewności, którą roztaczają wokół siebie tradycyjnie pojmowane i tradycyjnie praktykowane zależności hierarchiczno-biurokratyczne, $\mathrm{z}$ ich skłonnością do decydowania dyskrecjonalnego, o którym była mowa wcześniej. Nie we wszystkich wypadkach, ale w wystarczająco wielu, opóźnienia takie wynikają z oddziaływania tzw. ukrytych grup interesu, których antyrozwojowy charakter wobec dobra wspólnego dostrzegali nie tylko wspominany M. Olson ${ }^{22}$, ale i A. Podgórecki ${ }^{23}$, M. Crozier, E. Friedberg ${ }^{24}$, a także A. Zybertowicz ${ }^{25}$ oraz - nie tak znowu nieliczni - inni autorzy.

Co więcej, nawet jeśli przytomniejsi obywatele mają świadomość tego stanu rzeczy, to nie wywołuje ona chęci przełamania antyrozwojowego schematu, lecz wzmacnia skłonność do negatywnego uczenia się, dopasowywania się do zniekształconej, ale zarazem kostniejącej praktyki, z którą walczyć to jak „kopać się z koniem”26. Dzieje się tak już choćby z uwagi na powszechność biurokratycznych zaniechań, których skala tworzy wrażenie muru nie do przeskoczenia. Efektem tego stanu rzeczy jest systemowe odrzucanie reform, które dodatkowo odbywa się często bez większego rozgłosu, bo wynika z sumy drobnych opieszałości, niechęci, uprzedzeń, jednostkowych i grupowych egoizmów, środowiskowej mimikry czy zwykłej małoduszności.

Czynniki te razem składają się na efekt kuli śnieżnej, porywającej ze sobą wszystkie poważniejsze reformistyczne zamiary, które mogłyby zagrozić kontrolowanej sferze niepewności. Mamy tu więc do czynienia ze swoistym nieformalnym efektem skali. W takiej sytuacji albo nie ma winnych, gdyż winne są okoliczności, na karb których

22 M. Olson, op.cit.

23 A. Podgórecki, Kontrola społeczna trzeciego stopnia, Prace IPSIR UW, t. 1, Problemy profilaktyki społecznej i resocjalizacji, Wydawnictwa Uniwersytetu Warszawskiego, Warszawa 1976.

24 M. Crozier, E. Friedberg, op.cit.

25 A. Zybertowicz, Antyrozwojowe grupy interesów: zarys analizy, w: W. Wesołowski, J. Włodarek, Kręgi integracji i rodzaje tożsamości, Scholar, Warszawa 2005.

26 Por.: W. Morawski, Zmiana instytucjonalna. Społeczeństwo, gospodarka, polityka, Wydawnictwo Naukowe PWN, Warszawa 1998, s. 25-35. 
składa się niepowodzenie zmiany instytucjonalnej, albo winna jest opozycja polityczna i/lub winowajcami są interesariusze, którzy np. jakoby nie doceniają i nie rozumieją wyzwań stojących przed decydentami. Bywa oczywiście i tak, że interesariusze bronią swoich dotychczasowych enklaw uprzywilejowania i sprzymierzają się w tej walce z opozycją polityczną. Tak, czy inaczej, nie chodzi tutaj ani o wskazywanie „prawdziwych winnych” czy dociekanie - w czasie przeszłym lub teraźniejszym - kiedy i kto dopuścił się lub dopuszcza podobnych działań i zaniechań, ale o wskazanie na skalę tej niemocy. Można powiedzieć, że w Polsce jawi się ona jako ponadczasowa ${ }^{27}$.

$\mathrm{Z}$ zarysowanego powyżej powodu rodzimi decydenci mogą, mniej lub bardziej werbalnie, uznawać, że nie ma z kim i nie ma też o czym deliberować. Trudno też takim problemem, tj. brakiem partnerstwa i deliberacji, zainteresować opinię publiczną, gdyż - z uwagi na nieupowszechnienie wzorców dialogowych - nie ma ona pojęcia, o czym mowa i/lub ulega argumentacji ośrodków decyzyjnych i mediów, z których tylko nieliczne rozumieją tę problematykę. Zwykłemu obywatelowi te zdeformowane opinie wydają się często bliższe. Odległe są dlań, niewyraźne, wzory partnerstwa i deliberacji, odległe mu są propagujące je organizacje społeczne i gospodarcze. Dodatkowo podmioty te bywają niekiedy obarczane odium sensacyjnych uogólnień formułowanych w mediach.

Doświadczenie zwykle uczy obywatela, że w podobnej sytuacji należy: (a) pozostać nieufnym, gdyż ostrożności nigdy nie za wiele, a zarazem (b) szukać dojścia, protekcji, patrona, gdyż wobec nie do końca jasnej logiki sfery niepewności jedynie „bypassowanie”, umiejętne obchodzenie biurokratycznych sprzeczności może zbliżyć aktora do osiągnięcia rezultatu, o jaki zabiega. W wyborze tych nieformalnych ścieżek na skróty pomóc może patron, insider, który wciela się w rolę przewodnika po meandrach struktur nieformalnych. Patron jest zarazem strażnikiem dostępu strzegącym reguł nieformalnych przed światem zewnętrznym i w ten sposób, wraz z innymi oficjelami, współuczestniczy w ochronie kontrolowanej przez ten czy inny kolektyw sfery niepewności. Tak mniej więcej rysuje się struktura reformistycznej pułapki widziana z perspektywy wewnątrzadministracyjnych oddziaływań nieformalnych, wciągających w logikę sfery niepewności aktorów zewnętrznych, zniekształcających ich postrzeganie sytuacji oraz infekujących społeczne myślenie o istocie działania danej instytucji.

Czy jest wyjście z tej pętli? Wyjście jest, choć potrzeba wytrwałości, zrozumienia i poświęcenia czasu dla bezpośredniej komunikacji. Wypracowanie prawdziwej zmiany instytucjonalnej wymaga m.in. dalszych i niekłamanych inwestycji w czas

27 Zob.: A. Zybała, Polski umysł na rozdrożu. Wokół kultury umysłowej w Polsce. W poszukiwaniu źródeł niepowodzeń części naszych działań publicznych, Oficyna Wydawnicza SGH, Warszawa 2016. 
poświęcony spotkaniom. Spotykając się jedynie ze zwykłą częstotliwością znaną z wielu, choć nie wszystkich, dotychczasowych praktyk dialogowych ${ }^{28}$, omawiając sprawy typowe, przyjmując rozwiązania wprawdzie dostatecznie skuteczne, ale i zarazem standardowe, organizując zaplecze dialogu z małym zaangażowaniem zasobów wszystkich aktorów oraz spierając się ze sobą w dotychczasowym stylu, nie uda się do tej zmiany przybliżyć w zadowalającym tempie, być może w następnym pokoleniu, a może później. Ustalając wiele zagadnień zaocznie, wymieniając się jedynie plikami i korespondencją, nie przekraczając dzielących ludzi barier organizacyjnych, światopoglądowych, mentalnych, emocjonalnych, nie uda się do siebie zbliżyć na tyle, aby możliwe było praktykowanie partnerstwa i dialogu na poziomie porównywalnym z państwami, z których w tym zakresie chcielibyśmy brać przykład.

Nie oznacza to namawiania do zmiany poglądów, przynależności organizacyjnych, stylu życia czy jakiegoś drastycznego przewartościowywania myślenia oraz rewolucji w gospodarowaniu czasem. Nie, spodziewać się podobnych efektów byłoby niedorzeczne. Ludzie są przywiązani do swoich środowisk, praktyk, nawyków. Mają określone gradacje wartości, różne interesy, odmienne poglądy, inne szanse i inne ograniczenia - to jasne. Jednocześnie jednak mogą zarówno samodzielnie, jak i wspólnie myśleć, mogą rozważać, mogą poddawać ocenom. Wprawdzie ograniczają ich w tym instytucje kulturowe, działające jak swoiste filtry dla procesów myślenia, ale zarazem instytucjonalne wzorce nie myślą przecież za ludzi, nie są bytami niezależnymi od nas. Owszem, tkwią one w naszych umysłach, nabywamy je w toku życia społecznego, podsuwają nam rozmaite dyspozycje generalne, paradygmaty postrzegania i klasyfikowania, ale myślenia jako takiego nie zawłaszczają przecież w całości, choć zarazem je ukierunkowują, a to już bardzo wiele. W zwykłych warunkach nie odbierają jednak ostatecznie ludziom i woli, i możliwości wyboru.

Instytucje nie tylko samodzielnie nie myślą, ale i nie istnieją bez nas, w takim sensie jak np. obiektywne, bo istniejące i bez nas, tj. bez obserwatorów, prawa matematyki, fizyki, logiki, które możemy jedynie odkrywać, zbliżać się do nich koncepcyjnie, ale te prawa nie zależą przecież od nas. Kreujemy swój świat - to truizm, ale i fakt. Człowiek w szczegółach myśli sam. Sam obmyśla detale i konkrety oraz wymienia się (lub nie) tymi informacjami z innymi. Zatem, jeśli by od detali rozpocząć szerzej zakrojoną debatę, wówczas można zakładać, że z czasem także i generalia zaczną się, w toku deliberacji, powoli zmieniać. Ważne jest jednak, aby w codziennej powodzi szczegółów i natłoku bieżących spraw oraz konfliktów pamiętać, że poprzez nowe,

28 Zob. Np. Dialog społeczny na poziomie regionalnym. Ocena szans rozwoju, red. D. Zalewski, Instytut Pracy i Spraw Socjalnych, Warszawa 2005; Wybrane instytucje demokracji partycypacyjnej w polskim systemie politycznym, red. J. Sroka, Instytut Pracy i Spraw Socjalnych, Warszawa 2008. 
ale zarazem koncyliacyjne - tj. nastawione na dialog, a nie walkę - ujmowanie szczegółów staramy się dotrzeć do nowych (prodialogowych) kategorii ogólnych. Z czasem kategorie te mogą okrzepnąć w postaci nowych paradygmatów działania i wreszcie zakorzenić się jako nowe instytucje społeczne, które wystarczy odwzorować formalnie, powołując skuteczne instytucje publiczne. Aby jednak w zarysowany sposób starać się zmieniać nasze kulturowe podejście, potrzeba jeszcze znacznego wysiłku, śmielszej imaginacji, cierpliwości, metodycznego podejścia, no i bardziej wymiernego wzrostu zaufania. Tylko tyle, a zarazem aż tyle.

Wspominana w niniejszym artykule dyskusja wokół udziału partnerów społecznych w dialogu i partnerstwie w ramach funduszy strukturalnych i inwestycyjnych jest $\mathrm{w}$ gruncie rzeczy jedną $\mathrm{z}$ takich debat, których rezultat może utrwalać stary wzorzec lub go, jak się tutaj postuluje, przełamywać.

$* * *$

Tytułem podsumowania spójrzmy na problem egzekwowania prawa w jeszcze inny sposób, z początku bliższy argumentom potencjalnych oponentów, zwolenników administrowania w starym stylu i hipotetycznych „hamulcowych” pełnego wykorzystania możliwości formalnych celem wzmacniania, pogłębiania, upowszechniania dialogu i partnerstwa zgodnie $\mathrm{z}$ ich duchem.

Rozpocznijmy od pytania o zasadność wzmacniania, pogłębiania, upowszechniania dialogu i partnerstwa w bezwzględnie całym obszarze UE - poczynając od poziomu samej Unii, poprzez państwa, po społeczności lokalne. Zadajmy zatem na koniec ogólne, ale i zasadnicze, a zarazem sceptyczne w swoim wydźwięku pytanie o to, czy unijne prawa dialogowe mogą być, z podobnymi skutkami co na Zachodzie, wdrażane we wszystkich państwach członkowskich UE? M. Douglas, rozważając rzeczywiste, tj. kulturowo zakorzenione funkcjonowanie instytucji w społeczeństwach, pyta w pewnym momencie celniej i dobitniej, wykorzystując przykład z kręgu polityki imigracyjnej. Pyta o to, „czy zachodnie prawa zakazujące bigamii sprawdzają się przy regulowaniu stosunków między muzułmańskimi poligamistami w Londynie?"29.

Nasz przykład nie jest aż tak wyrazisty, ale sedno problemu jest takie samo i mieści się w pytaniu o to, czy daną formułę instytucjonalną (tj. monogamię, jak w przykładzie Douglas lub partnerstwo i dialog, jak w naszym wypadku) w ogóle się uda zakorzenić w środowisku społecznym, w którym wcale albo z rzadka była dotąd praktykowana, oraz czy po takiej modyfikacji system będzie działał lepiej.

29 M. Douglas, Jak myślą instytucje, tłum. O. Siara, Wydawnictwo Naukowe PWN, Warszawa 2012, s. 139. 
Przywołana autorka zastanawia się w związku z tym nad argumentacjami, których celem jest ocenianie konkretnych, formalnych systemów instytucjonalnych („systemów sprawiedliwości”, jak je nazywa). Chodzi tu o orzekanie, czy jeden system instytucjonalny jest lepszy od drugiego. Czy to łatwe zadanie? Nie dla każdego, ale dla specjalistów prawników jest ono wykonalne: juryści wciąż dokonują porównań różnych systemów sprawiedliwości. Sprostanie temu zadaniu jest technicznie łatwiejsze zwłaszcza wtedy, gdy w swoich analizach unikają oni nastawienia doktrynalnego, dogmatycznego ${ }^{30}$, tzn. nie stosują przy tym reguł legitymizujących ich własne instytucje, a więc np. reguł demokratycznych, analizując instytucje autorytarne i odwrotnie. W takiej sytuacji może ich np. interesować nie sam demokratyzm czy autorytaryzm jako wiodąca (choć zwykle nie dość jasna) idea uprawomocniająca porównywane systemy, ale np. spójność, efektywność, niearbitralność instytucji systemowych $\mathrm{w}$ rozpatrywanych wariantach. Zatem „analizować ludzkie systemy sprawiedliwości w sposób obiektywny jest równie łatwo, jak mierzyć ludzką stopę od pięty do palucha. Systemy można porównywać jako systemy. Nie można natomiast wybrać jakiejś konkretnej cnoty, np. równości (lub partnerstwa czy dialogu), a potem dowodzić, że zawsze i wszędzie (w każdej kulturze), jest ona słuszna i najlepsza. (...) Systemy można oceniać lepiej albo gorzej, w zależności od tego, na ile jesteśmy w stanie zrozumieć ich założenia"31.

A my? Czy rzeczywiście jesteśmy w stanie zrozumieć założenia odnoszące się do partnerstw i dialogu? Poszukując odpowiedzi, warto za M. Douglas zauważyć, że „zachowanie podczas kryzysu zależy od tego, jakie wzorce sprawiedliwości zostały zinternalizowane, jakie instytucje zyskały legitymizację”, czyli rzeczywiście się uprawomocniły ${ }^{32}$.

Mamy w Polsce sporo przykładów stopniowego (choć niewywołującego nadmiernego entuzjazmu) uprawomocniania się dialogu i partnerstwa jako reguł. Przykłady te pochodzą z poziomu centralnego, z regionów, a także partnerstw lokalnych, sektorowych czy sekcyjnych. W tym miejscu przywołamy jednak tylko jeden, bodaj najbardziej wyrazisty i stosunkowo świeży przykład. Chodzi o Pakiet działań

30 Każda postawa dogmatyczna wynika z imperatywu ideowego, który służy walce o terytorium ideowe, podobnie jak dogmat terytorialny nakazuje walczyć o terytorium fizyczne. Dogmaty nastawione są na walkę, dlatego nie pozostawiają więcej miejsca dialogowi, aniżeli wymaga tego paktowanie z przeciwnikiem i prowadzenie z nim gry dyplomatycznej. Przypomina to przykład, którym posługiwał się N. Luhmann przywołując komunikaty, jakie wymieniają między sobą zawodnicy znajdujący się w zwarciu podczas walki bokserskiej. „Dialog” ten ma służyć nie porozumieniu, ale osłabieniu przeciwnika, sprowokowaniu go do błędu. Zob. N. Luhmann, Teoria państwa bezpieczeństwa socjalnego, tłum. G. Skąpska, Wydawnictwo Naukowe PWN, Warszawa 1994.

31 M. Douglas, op.cit., s. 142.

32 Ibidem, s. 143. 
antykryzysowych ${ }^{33}$ z 2009 r. Już samo jego wypracowanie świadczyło o postępującym utrwalaniu się idei dialogu i partnerstwa w naszym życiu publicznym. Fakt ten jest tym bardziej wyrazisty, że Pakiet stanowił rezultat dialogu autonomicznego strony społecznej, a więc tej formy dialogu, która zalecana jest przez wiodące instytucje Zachodu i jest uznawana za bardziej zaawansowaną formę współpracy aniżeli scentralizowana trójstronność. W wypadku prac nad Pakietem mieliśmy do czynienia niemal z przykładem tzw. bipartyzmu, znanego m.in. z Finlandii, polegającego na ścisłej, dwustronnej kooperacji biznesu i pracy, która spotykała się $\mathrm{z}$ otwartą współpracą $\mathrm{rządu}^{34}$. Jednocześnie jednak wiemy, że nie uchroniło to samej Trójstronnej Komisji przed popadnięciem w głęboki kryzys, w dużej mierze wywołany, daleką od fińskiej, postawą rządowego centrum, czego ostatecznym efektem był kryzys i wprowadzenie nowej formuły ustawowej dla dialogu społecznego w Polsce ${ }^{35}$. Ówczesny kryzys Komisji, nie pierwszy zresztą i najpewniej nie ostatni, miał podłoże polityczne - tak dzieje się zwykle, gdy tzw. wielka polityka wypiera albo zastępuje politykę publiczną.

Wróćmy na koniec raz jeszcze do problemu przełamywania dawnych, kontrproduktywnych wobec dialogu, form instytucjonalnych. Otóż w dłuższej perspektywie na nic zda się tu nacisk, nie pomogą lobbing i dojścia, na nic się zdadzą, kapryśne ze swej natury, koalicje z politykami partyjnymi. Nie ma tu innej drogi niż partnerska i możliwie powszechna oraz autonomiczna deliberacja. Lepiej zarazem, jak się rzekło, rozmawiać o szczegółach w nadziei, że kumulacja rezultatów dialogu nad detalami przyniesie skutek w postaci przełamania wzorca scentralizowanego i bardziej powszechnego zaistnienia nowej, partycypacyjnej formuły instytucjonalnej. Skoro bowiem działające kategorie prawa są zakorzenione w strukturze normatywnej i moralnej, powiązane z obowiązkami oraz ugruntowane w codziennym porządku społecznym, a porządek ten współcześnie kształtowany jest głównie w obszarze podziału pracy - to nasza wiedza i samowiedza o roli dialogu w polityce publicznej muszą wynikać z wniosków płynących z dyskusji nad istniejącymi i możliwymi sposobami reorganizowania zasad kooperacji społecznej ${ }^{36}$.

Aby rozmowy coś wnosiły, aby były konkluzywne, należy przypisywać określone wagi rozważanym wspólnie problemom - oceniać je, ważyć, a następnie wykluczać niżej ocenione alternatywy ${ }^{37}$. Bezalternatywna deliberacja do niczego nie prowadzi, aby współdecydować, trzeba mieć możliwość odrzucania pewnych rozwiązań

33 Zob. http://www.mpips.gov.pl/praca/pakiet-antykryzysowy/, dostęp: 25.07.2017.

34 Europejskie..., red. J. Sroka, op.cit., s. 77, 78.

35 Ustawa z dn. 24 lipca 2015 roku o Radzie Dialogu Społecznego i innych instytucjach dialogu społecznego, Dz. U. 2015, poz. 1240.

36 M. Douglas, op.cit., s. 119, 137.

37 A. Sen, Nierówności. Dalsze rozważania, tłum. I. Topińska, Znak, Kraków 2000, s. 60-63. 
na podstawie ocen wynikających z możliwie obiektywnych i przedyskutowanych miar. Trzeba mieć możliwość realnego wyboru popartego racjonalną, opartą na dowodach, ale i dialogowo ukierunkowaną argumentacją, której niestety niekiedy próżno szukać w niektórych opiniach partnerów, odpowiedziach urzędowych czy posunięciach legislacyjnych. Widać to m.in. na przykładach wypowiedzi, które formułowano przy okazji sporu o kształt partnerstwa w funduszach strukturalnych i inwestycyjnych.

Obecnie wstępnej klasyfikacji kierunków, w których powinny rozwijać się dialog i partnerstwo w naszej części świata, dokonuje się na poziomie ponadpaństwowym. Mamy na to wpływ, ale jest on wkomponowany w polityczne i proceduralne realia Unii Europejskiej. Klasyfikacje te płyną z uogólnień i konwencji wypracowywanych w dużej, jeśli nie przeważającej mierze, z doświadczeń społeczeństw i systemów, które mają dłuższą i bardziej różnorodną historię współdecydowania. Jeśli więc się z nimi godzimy, jeśli je formalnie legitymizujemy, jeśli przyjmujemy te argumenty i chcemy się rozwijać zgodnie z wytyczaną przez nie drogą, wówczas niewielkie pozostaje nam pole manewru. Można jedynie $z$ jakichś przyczyn opóźniać ten proces i z elementami takiego właśnie podejścia mamy niekiedy do czynienia ze strony administracji, ale i partnerzy nie są od tego wolni. Ich zyskiem w tym spowalnianiu jest utrzymywanie aktualnego układu sił, wraz z kontrolowanymi przez poszczególnych aktorów strefami niepewności. Za działanie to jednak przychodzi płacić efektywnością funkcjonowania całego układu partnersko-dialogowego, który ostatecznie i tak, w sposób mniej lub bardziej ułomny, prędzej czy później, przyjdzie nam wdrożyć, zgodnie z partycypacyjno-innowacyjnymi kierunkami rozwoju polityki publicznej preferowanymi w Unii Europejskiej.

\section{Bibliografia}

Crozier M., Friedberg E., Człowiek i system. Ograniczenia działania zespołowego, tłum. K. Bolesta-Kukułka, PWE, Warszawa 1982.

Czapiński J., Stan społeczeństwa obywatelskiego, w: Diagnoza społeczna 2015. Warunki i jakość życia Polaków, red. J. Czapiński, T. Panek, Rada Monitoringu Społecznego, Warszawa 2015.

Dialog społeczny na poziomie regionalnym. Ocena szans rozwoju, red. D. Zalewski, Instytut Pracy i Spraw Socjalnych, Warszawa 2005.

Douglas M., Jak myśla instytucje, tłum. O. Siara, Wydawnictwo Naukowe PWN, Warszawa 2012. Hardin G., The Tragedy of the Commons, "Science, New Series” 1968, Vol. 162.

Kiersztyn A., Granice brudnej wspólnoty, w: Idee naukowe Adama Podgóreckiego, red. J. Kwaśniewski, J. Winczorek, Prace Katedry Socjologii Norm, Dewiacji i Kontroli Społecznej IPSIR UW, t. 10, PTS - IPSIR UW, Warszawa 2009. 
Kwieciński L., Analiza praktycznych rozwiązań wzmacniania potencjału partnerów społecznych $w$ odniesieniu do Europejskiego kodeksu postępowania $w$ zakresie partnerstwa $w$ ramach europejskich funduszy strukturalnych $i$ inwestycyjnych, niepublikowany maszynopis, ekspertyza przygotowana na zlecenie Dolnośląskiej Rady Dialogu Społecznego, Wrocław 2016.

Luhmann N., Teoria państwa bezpieczeństwa socjalnego, tłum. G. Skąpska, Wydawnictwo Naukowe PWN, Warszawa 1994.

Majone G., Dowody, argumenty i perswazja w procesie politycznym, tłum. D. Sielski, Scholar, Warszawa 2004.

Merton R.K., Teoria socjologiczna i struktura społeczna, tłum. E. Morawska, J. Wertenstein-Żuławski, Wydawnictwo Naukowe PWN, Warszawa 2002.

Morawski W., Zmiana instytucjonalna. Społeczeństwo, gospodarka, polityka, Wydawnictwo Naukowe PWN, Warszawa 1998.

Olson M., The Logic of Collective Action: Public Goods and the Theory of Groups, Harvard University Press, Cambridge 1965.

Ostrom E., Beyond Markets and States: Polycentric Governance of Complex Economic Systems, "American Economic Review" 2010, Vol. 100.

Ostrom E., Collective Action and the Evolution of Social Norms, "Journal of Economic Perspectives" 2000, Vol. 14.

Peters B.G., Administracja publiczna w systemie politycznym, tłum. K.W. Frieske, Scholar, Warszawa 1999.

Podgórecki, A., Kontrola społeczna trzeciego stopnia, „Prace IPSIR UW”, t. 1, Problemy profilaktyki społecznej i resocjalizacji, Wydawnictwa Uniwersytetu Warszawskiego, Warszawa 1976.

Sen A., Nierówności. Dalsze rozważania, tłum. I. Topińska, Znak, Kraków 2000.

Sroka J., Czy nieformalne wzorce kulturowe oraz formalne instytucje nadążaja za potrzeba partnerstwa i dialogu? Czy i ewentualnie w jaki sposób można wzmacniać potencjat strony społecznej $w$ ramach partnerstwa i dialogu $w$ europejskich funduszach strukturalnych $i$ inwestycyjnych?, niepublikowany maszynopis, ekspertyza przygotowana na zlecenie Dolnośląskiej Rady Dialogu Społecznego, Wrocław 2016.

Sroka J., Europejskie stosunki przemysłowe w perspektywie porównawczej, Wydawnictwo Uniwersytetu Wrocławskiego, Wrocław 2000.

Wybrane instytucje demokracji partycypacyjnej w polskim systemie politycznym, red. J. Sroka, Instytut Pracy i Spraw Socjalnych, Warszawa 2008.

Zybała A., Polityki publiczne, Krajowa Szkoła Administracji Publicznej, Wydawnictwo Kontrast, Warszawa 2012.

Zybała A., Polski umysł na rozdrożu. Wokół kultury umysłowej w Polsce. W poszukiwaniu źródeł niepowodzeń części naszych działań publicznych, Oficyna Wydawnicza SGH, Warszawa 2016.

Zybertowicz A., Antyrozwojowe grupy interesów: zarys analizy, w: W. Wesołowski, J. Włodarek, Kręgi integracji i rodzaje tożsamości, Scholar, Warszawa 2005. 